\title{
The Influence of Geographical Factors on Formation of Jinggangshan Red Culture--Based on the Formation and Promotion of Jinggangshan Red Culture Analysis
}

\author{
Li Wang \\ Xi'an Peihua University; Xi'an 710125 China
}

Keywords: geographical factors; Red culture; The Jinggang Mountains. Revolution.

\begin{abstract}
The red culture of China is a multi-cultural system with distinct political meaning formed in the process of the struggle and summarization of countless revolutionary ancestors in modern times. The production of red culture is not an accident, it is based on a certain geographical and cultural element. It is meaningful to analyze the birth of red culture from geographical factors base on the case of Jinggangshan. The natural ecology and rich natural resources of Jinggangshan region plays a positive role in many aspects of the local economic, social and the humanities, at the same time also provides a suitable condition for the birth of Jinggangshan red culture. To analyze the formation of the red culture in Jinggangshan from the perspective of geographical factors is conducive to our deeper understanding of the value of the red culture in Jinggangshan.
\end{abstract}

\section{Introduction}

Red, an extraordinary symbol of Chinese spirit, is the main color of the flag of the communist party of China and the Chinese national flag. Since the 1920s, the Chinese people have demonstrated the courage and fearlessness during the war against foreign invasion and the realization of the independence and self-improvement of the Chinese nation. Deeply rooted in the hearts of the people, the symbol of red revolution as a guide and unity of the Chinese people of all ethnic groups in resistance to outside, the great strength of sockets red gradually become a kind of uplifting cultural image, full of vigor and vitality. At the same time, during the process of the generation of the red culture in China, many red culture bases have walk into sight of Chinese people, they are promoting the red culture as a perennial power and cultural appeal, at the same time, they also carry the hope of the red culture in the new period. Based on this historical background, this paper carried out a systematic analysis of the geographical elements of Jinggangshan red culture to clarify the origin and development of the red culture with Chinese characteristics.

\section{Overview of Chinese Red Culture.}

China's red culture is not a traditional culture form, and the revolution and political culture in traditional Chinese culture have no such lasting influence as the red culture of China [1]. Back to its origin, the red culture originated in the $1920 \mathrm{~s}$, the establishment of the communist party of China declared the arrival of a new revolution, through this period, the relevant researchers believe that the Chinese red culture as a kind of specific forms of culture has been initially formed. The original Chinese red culture is enthusiasm, passion, it expounded the new-democratic revolution in the process of struggle of several essential stages, so the red culture is regarded as the symbol of communism.

At the same time, some people think that red is Cultural Revolution literature, cultural relics, literary and artistic works, revolutionary relics and sites that formed during the Chinese revolution. Some people has done some research about red culture resources in the targeted research, such as Liu Xiyuan take red culture as a kind of value form that has important significance to the new democratic revolution and the socialist construction.

Overall, red culture supports Marxism as the core, and it absorbs the essence of Chinese traditional culture, which is the result of the development of Marxism in China. 
Red culture has different meaning in different period, for example, in the period of new-democratic revolution, the red culture is more represents a kind of ideology, it takes the communist party as the leader, absorb the practical experience that gain from the revolutionary practice process, the theme of the red culture in this period is hard struggle. After the founding of new China, the function and significance of the red culture also has been fundamentally changed from leading to realizing the great revival of the Chinese people of all ethnic groups to complete the construction of the primary stage of socialism, the red culture concept and the kernel is changeless, but has a task and significance differences [2].

In the process of continuous development, the Chinese red culture has risen from a kind of cultural form to a social phenomenon, academic circles have different understanding to this, for example, Wangyidi think that red culture is constructed by four elements, main body-- the birth of the communist party of China; Practical basis -- the new democratic revolution; The sinicization of western thought - the combination of marxism and Chinese characteristics; The reinvention of culture -- the transformation and modernization of the excellent traditional culture of the Chinese nation.

With the construction of the socialist new China, the red culture has become broader and more diversified. It has changed from the previous single political culture form to the organic unity that combining of material culture, system culture, spirit culture. This transformation has a great significance to the red culture.

\section{Analysis of the Red Culture of Jinggangshan Based on Geographical Factors.}

The formation and development of culture has a significant correlation with cultural regionalism and natural ecology and social ecology.

In the production ofJinggangshan red culture, geography factor plays a multiple role. It not only nourishing its growth as fertile soil, but also promote the development of red culture in history, economic, cultural and many other aspects. As a red revolutionary cultural resort, Jinggangshan area is an important part of Chinese red culture.

\subsection{Analysis of Topographic and Geomorphological Factors.}

Jinggangshan City is in mountain topography that near the border of Hunan and Jiangxi, beside the middle part of the Luo Xiao Mountains. The average elevation of the city is 381.5 meters, and the main peaks are more than kilometers above sea level, and the highest peak in the city is 1841 meters above the sea level. The weakest region of Kuomintang reactionaries concentrated blockade forces is mountainous area. The geographical environment is sinister, which is not conducive to the attack of large motorized troops. This natural advantage facilitates the survival and development of the communist party and the red army. The original forest and the mountains in the Jinggangshan area have become a good barrier for the enemy to carry out the annihilation plan for our army. Such terrain brings bad living environment but gave birth to the revolutionary spirit of self-reliance, industrious and hard work of our party and army, use of the resources of nature be self-sufficient, to carry out the agrarian revolution, expand farmers' regime, basic implementation the agrarian revolutionary war in the early stages of the military power and political deployment, development, promoted the original red culture germination. We learned to use nature resources to achieve self-sufficiency, to carry out the agrarian revolution, expand farmers' regime, implements the military power and political deployment at the beginning of the agrarian revolutionary war period of the development, promoted the original red culture.

\subsection{Analysis of Climate and Resource Elements.}

Jinggangshan region belongs to subtropical monsoon climate zone, four seasons here is distinct and the annual rainfall here is adequate. The annual average temperature is 23.9 degrees Celsius. Affected by the high mountains around, warm and moist air can hardly influent here, which lead to the long winter and short summer climate characteristic. Climate factors affect the forest biological resources in Jinggangshan. The Jinggangshan region has the most intact primeval forest in the same latitude, there are many famous tree species such as wood of stocking, ginkgo, sightseeing and all 
kinds of plants with consumption and the economic efficiency. Influenced by the favorable climate and resources, Jinggangshan region has advantaged superiority to the production of red characters and personality. With its rich natural resources, pleasant scenery and pleasant climate, the people here have gradually developed a simple and honest and optimistic life value. Faced with the natural ecology of high clouds and abundant water, they can appreciate the harmony between man and nature, and thus have lofty spiritual pursuit and ideal faith. This is beneficial to the root of Chinese red culture; the red army of workers and peasants implement the instructions of the Chinese communist party spirit here. Combined with the local diligent, hard-working character, it formed the unique red culture about, loyal and trustworthy ideal faith [4].

\subsection{Analysis of Economic Geography Factors.}

The geographical advantage of Jinggangshan region makes it have certain economic benefits, which is why the party central committee chose to take root in Jinggangshan area and build up strength for prosperity. There are many economic and geographical factors in Jinggangshan area, such as water resources, mineral resources, biological resources, land resources, etc., all of them could become an advantage with a little development. There are a lot water resources in Jinggangshan area, such as Longjiang which belong Ganjiang River, etc., in addition to the natural water system, there are five large reservoirs, water resources here are more than 1.1 billion cubic meters. In terms of mineral resources, Jinggangshan is rich in minerals such as gold, graphite, crystal, asbestos, rare earth and other minerals, which are widely distributed throughout the city. "People are rich because of the local resources" is the best portrayal of the Jinggangshan area. The unique economic geography of the red culture in Jinggangshan region comes from this. According to "the Jinggangshan Revolution" records, the agrarian revolution period, the landlord class in Jinggangshan occupy more than $45 \%$ of the available land resources, the local rich peasants occupy $10 \%$ share, old money land occupy $10 \%$, temple field occupy $7 \%$, and the farmers' land accounts for only $25 \%$. The landlord used the advantage of land resources to accumulate evil capital and made cruel exploitation of the peasants. land revolution that lead by the communist party of China attach the importance of farmers' assets and economic demand, fully use in Jinggangshan original economic geography factors, adjust measures to local conditions, expanding development, led the local farmers fight against the local tyrants and evil gentry, abolished heavy taxes, formed a good mass base. At the same time, under the direction of red culture and belief, with the understanding of the people's power, party's older generation proletariat revolutionaries lead broad masses of the people achieve self-sufficiency in the product life with Jinggangshan profound geographical resources. They expand the revolutionary base areas of red fruit, let common people absolutely trust the leadership of the party, which is condition that gave birth to red political power and the red culture and important basis for the new victory which produces [5].

\section{Analysis of the Development of the Red Culture of Jinggangshan from the Aspect of Geographical Factors.}

The great bank of the mountain and the rolling of water make the Jinggangshan people have the unselfish and fearless attitude of calm. They are selfless because the war almost destroyed their homes, but they also built a stronger barrier in their hearts. Their selflessness lies in the greater ideal that they would leave the hope of life to their friends and future generation even sacrifice their precious life. Zhang Lingbin colonel, for example, as a staunch revolutionary fighter, in the process of the red army long march of twenty-five thousand miles, when he's responsible for the strategic shift of troops marching plans, he also takes care of the wounded soldier. He also provides material support and medical rescue services, dedicate himself unselfishly. Treating thousands of red army soldiers, he often forgets to eat, even fall ill because of the busy. All of this shows that in the special natural geographical environment, Jinggangshan people has become courageous and enthusiastic. Their spirit into the red culture, even today, the spirit of outstanding communist like Zhang Lingbin still is remembered by contemporary communists in each heart, and it is their dedication and tireless 
efforts achieve success of the great China. It also makes the red culture have more abundant meaning in practical application, make the red culture inheritance and carry forward constantly.

\section{Summary}

To sum up, this paper elaborates the important conditions for the generation and development of the red culture of Jinggangshan based on the geographical factors. Red culture has become an important spirit banner in the process of sinicization of Marxism. The red culture base of Jinggangshan is the red cultural base with the deepest foundation and influence of geographical factors. Therefore, it is of great practical significance to study it. Through the research of this paper, we declared the view that the red culture of China is a characteristic cultural form with profound political meaning and elaborated the characteristics of Chinese red culture. We explain the underlying causes why the red culture has become a social and geographical phenomenon. After that, we analyzed its unique geological features, climate and resource elements, economic geography factors and other three aspects. These aspects are the important intrinsic factor of the Jinggangshan area to become the base of Chinese red culture. The analysis of the red culture of Jinggangshan based on geographical factors can better highlight the realistic role of red culture and promote the modern construction of red culture.

\section{References}

[1]. Deng Xianchao, Deng Haixia. A review of the research on the concept of red culture in China in 10 years [J]. Journal of Jinggangshan university (social science edition), 2016, 37(01):29-39.

[2]. Jin Minqing. Contemporary construction of the spiritual inheritance and ideal belief of red culture [J]. Journal of Jinggangshan university (social science edition), 2015, 36(01):15-19.

[3]. Liu Hongmei. Research on the inheritance of red tourism and red culture [D]. Xiangtan University, 2012.

[4]. Jiang Feng, Wang Yingzi. System factor dialysis generated by Chinese red culture -- a case study of the red culture of Dachan Mountains[J]. Journal of Beijing normal university (social science edition), 2010(06):89-97.

[5]. Zhang Tai, Chang Sheng. Cultivation of red cultural resources and socialist core values [J]. Practical, 2016(11):30-35. 